\title{
Characteristics and Significance of the Transition Zone in Drained Thaw-Lake Basins of the Arctic Coastal Plain, Alaska
}

\author{
J.G. BOCKHEIM ${ }^{1}$ and K.M. HINKEL ${ }^{2}$
}

(Received 22 November 2004; accepted in revised form 24 May 2005)

\begin{abstract}
In the three-component conceptual model of arctic soils, the transition zone is recognized as a layer intermediate between the seasonally thawed active layer above and the stable permafrost below. Although typically frozen and therefore part of the near-surface permafrost, the transition zone episodically thaws over a time period ranging from sub-decadal to multicentennial. From an analysis of 138 pedons from the Arctic Coastal Plain near Barrow, Alaska, we were able to delineate the upper boundary of the transition zone in $78 \%$ and the lower boundary in $70 \%$ of the pedons. The transition zone exhibits the effects of cryoturbation, contains abundant redistributed organic carbon, is enriched by ice in the forms of lenses, veins, and nets (reticulate vein ice) and has abundant soil moisture. The surface (upper boundary) of the transition zone is found at an average depth of 34 $\pm 7 \mathrm{~cm}$ below the ground surface and has an average thickness of $23 \pm 8 \mathrm{~cm}$. We observed no significant differences in the thickness of the transition zone or the depth of its boundaries in drained thaw-lake basins ranging in age from 300 to 5500 years BP, suggesting that the processes leading to the development of this zone occur rapidly in Arctic Alaska. Recognition of the transition zone has implications for understanding pedogenic processes in permafrost-affected soils and for determining the response of near-surface permafrost to climate warming.
\end{abstract}

Key words: active layer, Alaska, arctic soils, frozen ground, permafrost, transition layer

RÉSUMÉ. Dans le modèle conceptuel à trois composantes des sols arctiques, la zone de transition est reconnue comme une couche intermédiaire entre la couche active supérieure qui dégèle selon les saisons et le permafrost stable au-dessous. Bien qu'elle soit généralement gelée et que par conséquent, elle fasse partie du permafrost près de la surface, la zone de transition dégèle de manière épisodique sur une période allant de moins d'une décennie à plusieurs centaines d'années. D'après l'analyse de 138 pédons provenant de la plaine côtière de l' Arctique près de Barrow, en Alaska, on a pu délimiter la borne supérieure de la zone de transition dans $78 \%$ des pédons et la borne inférieure dans $70 \%$ d'entre eux. La zone de transition affiche les effets de la cryoturbation, puis elle contient du carbone organique distribué en abondance, elle est enrichie par la glace sous la forme de lentilles, de veines et de réseaux (glace de veine réticulée) et son sol renferme une humidité abondante. La surface (borne supérieure) de la zone de transition se trouve à une profondeur moyenne de $34 \pm 7 \mathrm{~cm}$ sous la surface du sol et son épaisseur moyenne est de $23 \pm 8 \mathrm{~cm}$. Aucune différence considérable n'a été observée quant à l'épaisseur de la zone de transition ou à la profondeur de ses bornes dans les bassins de lacs de dégel allant de 300 à 5500 ans BP, ce qui laisse croire que les processus ayant mené au développement de cette zone se produisent rapidement dans l'Alaska arctique. La reconnaissance de la zone de transition a des incidences sur la compréhension des processus pédogénisés dans les sols affectés par le permafrost ainsi que sur la détermination de la réaction du permafrost situé près de la surface au réchauffement du climat.

Mots clés: couche active, Alaska, sols arctiques, sol gelé, permafrost, couche de transition

Traduit pour la revue Arctic par Nicole Giguère.

\section{INTRODUCTION}

In many natural systems, there exists a transition layer between regions of contrasting properties. In lakes, for example, the thermocline separates warmer waters above from colder waters below. In this transition zone, the thermal properties and temperature gradients differ from those of the upper and lower layers. Furthermore, the characteristics of this transition layer are temporally variable, in that the position of the upper and lower boundaries can change with time, and the layer may periodically or episodically disappear. The same is true of the boundary layer in the atmosphere, where a three-layer model is also appropriate and useful in understanding system dynamics.

The standard conception of permafrost-affected soils employs a simple two-layer model. At depth is permafrost, which is defined as "earth material that remains continuously at or below $0^{\circ} \mathrm{C}$ for at least two consecutive years" (van Everdingen, 1998). At the surface is the "active layer," which thaws in summer and refreezes in winter.

Recent research in North America supports an earlier Russian proposal for the existence of a "transition" or

${ }^{1}$ Department of Soil Science, University of Wisconsin-Madison, Madison, Wisconsin 53706-1299, U.S.A.; bockheim@ wisc.edu

${ }^{2}$ Department of Geography, University of Cincinnati, Cincinnati, Ohio 45221-0131, U.S.A.; kenneth.hinkel@uc.edu

(C) The Arctic Institute of North America 
"transient" layer in Arctic soils (Shur et al., 2005). This layer-the uppermost, or near-surface, portion of the permafrost-meets the thermal criteria for permafrost defined above. However, its maximum summer-thaw depth tends to fluctuate from year to year owing to interannual variations in components of the surface energy budget. During occasional deep-thaw penetration, ice in the nearsurface permafrost melts, and the affected zone temporarily becomes part of the active layer. It is expected that these episodic thaw events will occur less often at greater depth, or in other words, that the thaw recurrence interval increases with depth within the transition zone (Shur et al., 2005). On a time scale ranging from sub-decadal to multicentennial, all or some of this zone temporarily thaws. This thawing is viewed as a response to interannual variation and possibly also to longer-term climate changes. The base or lower boundary of the transition zone, therefore, marks the position of maximum thaw over the time interval. This boundary can be considered the long-term permafrost table.

Following episodic deep thaw, the affected portion of the transition zone returns to the frozen state. The unique history of this zone produces characteristics that differ from both the active layer above and the deeper permafrost below (Yanovsky, 1933; Shur, 1988a, b). As a result, the transition zone has a large impact on soil and cryogenic structures and on the thermal stability of permafrost.

The objectives of this paper are to (1) distinguish and delineate the transition zone using a comprehensive database from soil cores collected near Barrow, Alaska; (2) identify those soil properties that characterize the transition zone; and (3) discuss the influence of the transition zone on soil development.

\section{GEOCRYOLOGICAL ASPECTS OF THE TRANSITION ZONE}

Numerous studies have demonstrated that the nearsurface permafrost, including the transition zone, is icerich, and its ice content is often much greater than in the deeper permafrost immediately below (Brown, 1967b; Mackay, 1971, 1972, 1983; Sellman et al., 1975; Pollard and French, 1980; Cheng, 1983; Shur, 1988a, b). Ice enrichment occurs over time by infiltration of snow meltwater down thermal contraction cracks, where it subsequently freezes at depth (Hinkel et al., 1996, 2001). In addition, moisture is drawn from wet, unfrozen soil downward into the frozen zone, where it forms segregation ice (Williams, 1982; Mackay, 1983). Therefore, the upper permafrost and transition zone contain interstitial pore ice, lenses of segregation ice, and ice veins and, in time, become supersaturated with ice. Episodic thaw of portions of the transition zone will, in a sense, reset the moisture content back to a base level.

The transition zone occasionally experiences thaw, especially during warm summers and near its upper boundary.
As thaw frequency decreases with depth, the probability of thaw at the long-term permafrost table approaches zero. The ice-rich transition zone has high resistance to thaw because latent heat is required to melt the ice, and this resistance increases over time as the ice content increases. Therefore, the transition zone tends to promote interannual thermal stability in the upper permafrost (Shur, 1977; Shur et al., 2005). Should the thaw front penetrate well into this ice-rich layer, it may trigger additional processes. When ground ice melts, the ground surface will subside, and the soil at depth loses strength while pore water pressure increases. Lewkowicz and Clarke (1998) used field observations and modeling to link deep thaw to shear displacement within the transition zone. This phenomenon occurred during particularly warm summers and resulted in increased rates of solifluction on slopes.

Secondary and tertiary ice wedges and contemporary ice veins are occasionally observed extending from primary ice wedges upward into the transition zone (Fig. 1). These features indicate ice-wedge rejuvenation following deep thaw events (Lewkowicz, 1994; Kokelj and Burn, 2003). Primary ice wedges, in contrast, are located at the long-term permafrost table, as observed at Barrow (Brown, 1969; Shur, 1975; Estabrook and Outcalt, 1984). Therefore, the tops of primary ice wedges indicate the maximum depth of thaw that has occurred since the ice wedges formed, which coincides with the long-term permafrost table and the base of the transition zone.

In the drained thaw-lake basins in Alaska, the cryogenic structure of the lower region of the transition zone differs from that of the underlying permafrost in that it contains a net-like structure (Popov, 1967; Murton and French, 1994), whereas the underlying deeper permafrost contains primarily ice lenses. Shur (1988a, b) related the genesis of the transition layer to a decrease in the active-layer depth during ecosystem evolution, primarily under the impact of vegetation succession or accumulation of material at the soil surface. However, the near-surface permafrost might be enriched in ice without active-layer thinning (Cheng, 1983). Vegetation and organic debris tend to insulate the ground and thus reduce heat flow to depth, while surface aggradation is accompanied by upward migration of the permafrost table. As the surface layer accumulates, the thermal properties change; over millennia, the active layer becomes thinner, shielding the ground from extreme events.

Ice accumulation at depth produces frost heave, which influences microrelief and thus ecological conditions on the soil surface and in the active layer. Kokelj and Burn (2003) correlated "drunken forests" with the accumulation of aggradational ice in the upper permafrost, and Shur and Ping (1994) demonstrated the influence of such ice on patterned-ground evolution.

Although the transition zone is not specifically mentioned, there is some recognition of its occurrence in the cryopedology literature (Tarnocai, 1994; Hoefle et al., 1998). The transition zone often exhibits more intensive cryoturbation and greater admixed organic matter than 


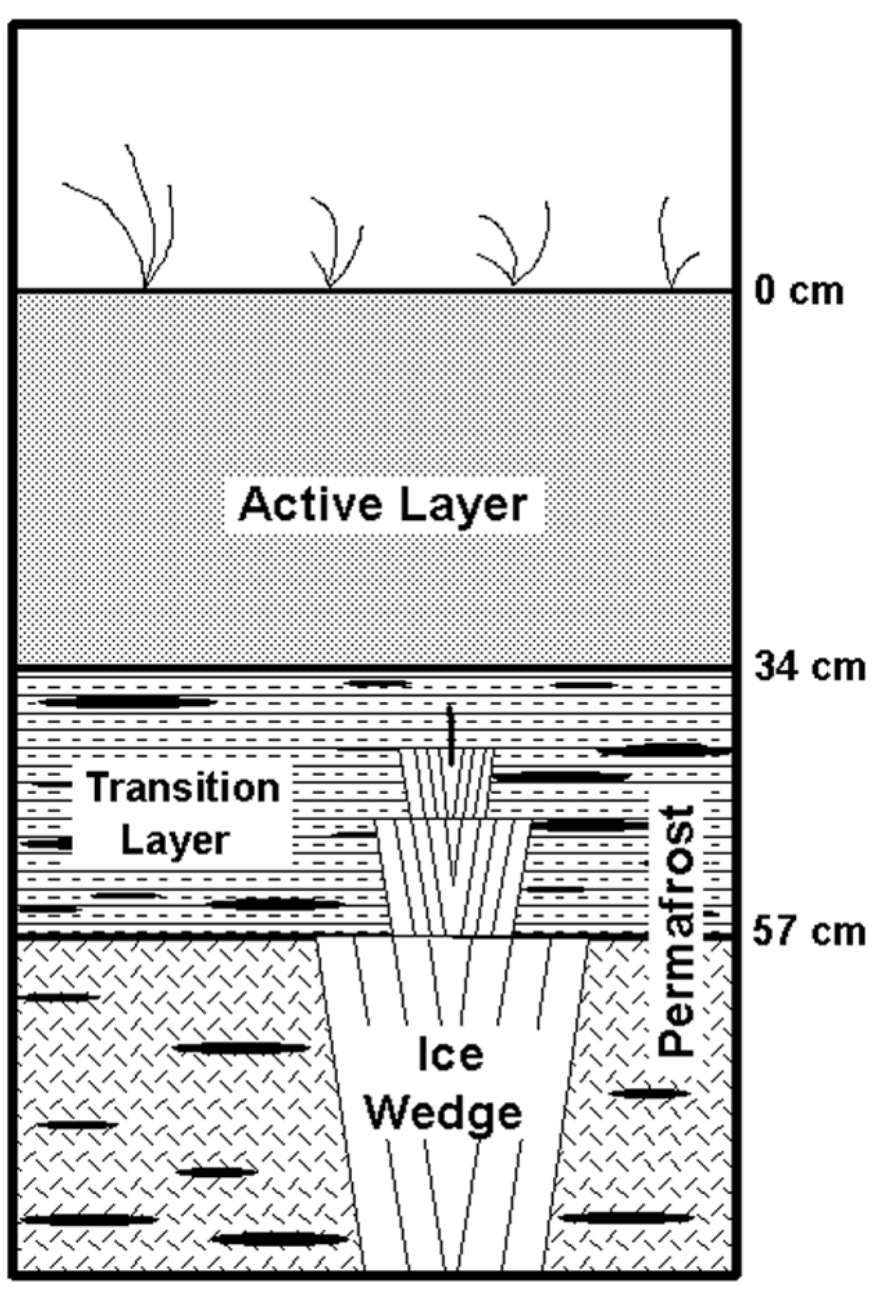

FIG. 1. Schematic diagram of a three-layer conceptual model. Note formation of ice lenses (black ellipses), upward growth of secondary and tertiary ice wedges into transition zone (from Fig. 4 in Lewkowicz, 1994), and ice vein protruding from tertiary ice wedge.

underlying permafrost (Brown, 1965a, b, 1969). Cryoturbation refers to sorting, heaving, stirring, wedging, and cracking (Washburn, 1980) and is evidenced by broken and irregular soil horizon boundaries, textural bands, organic matter accumulation in the subsoil, oriented stones, silt caps and accumulations, and deformed soil material associated with movements due to ice- and sand-wedge growth (Bockheim and Tarnocai, 1998). Soil fabrics in the transition zone, as detected in thin sections, reflect rotation caused by cryoturbation (Fox and Protz, 1981; Smith et al., 1991). The transition zone often has a massive prismatic or platy structure resulting from ice lensing (Smith et al., 1991; Tarnocai, 1994). It is less weathered than the active layer (Brown, 1969; Tarnocai, 1972), and it exhibits higher soil moisture than the active layer because of abundant segregation and vein ice (Tarnocai, 1983).

The concept of the transition zone is embedded in the definition of gelic materials in the Gelisol order of Soil Taxonomy (Soil Survey Staff, 1999). Gelic materials may be either mineral or organic and are affected by cryoturbation, ice segregation, cracking due to thermal contraction or a combination of these factors (Bockheim et al., 1997). Cryopedogenic processes that lead to gelic materials are driven by the physical volume change in water as it turns to ice, moisture migration along a thermal gradient in the frozen system, or thermal contraction of the frozen material by continued rapid cooling; all these occur in the transition zone.

Soils of Arctic Alaska are strongly related to regional climate (Ping et al., 1998), land cover type (Auerbach et al., 1996), micro-relief (patterned ground) form (Drew and Tedrow, 1962; Everett, 1974), chemical composition (Walker and Everett, 1991; Walker et al., 2000), and age of parent materials (Munroe and Bockheim, 2001). Soils of Arctic Alaska are often intensively cryoturbated and generally have a medium texture, poor drainage, and high organic matter content (Tedrow, 1962; Brown, 1969; Ping et al., 1998).

Over the past decade, we have been describing and sampling soils in the Arctic Coastal Plain near Barrow, Alaska (Bockheim et al., 1999, 2002, 2004). Soils information was incorporated into a database that includes descriptions and analytical data for 138 pedons.

\section{STUDY AREA}

The study was conducted near Barrow, Alaska $\left(71^{\circ} \mathrm{N}\right.$, $\left.156^{\circ} \mathrm{W}\right)$ on the Arctic Coastal Plain, where elevations range from 0 to $20 \mathrm{~m}$ above sea level. The study area is within the zone of continuous permafrost (Péwé, 1975). Although generally around Barrow the thickness of the active layer ranges from 30 to $90 \mathrm{~cm}$ (Nelson et al., 1998), in the drained thaw-lake basins during 1995-2003 it was $32 \pm 4.4 \mathrm{~cm}$ (Nelson et al., unpubl.). The mean annual air temperature is $-12.0^{\circ} \mathrm{C}$; July is the warmest month at $4.7^{\circ} \mathrm{C}$, and February is the coldest month at $-26.6^{\circ} \mathrm{C}(\mathrm{Na}-$ tional Climate Data Center, 2002). Mean annual precipitation is about $100 \mathrm{~mm}$, two-thirds of which falls as rain during the three-month period July-September. The winter snowpack averages 20 to $40 \mathrm{~cm}$, but snow accumulation is highly variable because of terrain microtopography and drifting caused by strong easterly winds.

Five major landcover types occur near Barrow: dry heath, dry meadow, moist meadow, wet meadow, and emergent aquatic vegetation (Tweedie, 2004). The parent materials are dominantly marine sediments of Pleistocene age that have been reworked by thaw-lake processes on the Arctic Coastal Plain (Sellman and Brown, 1973; Carter, 1988). The majority of cores in the database were collected from within drained thaw-lake basins, which represent four age classes: young $(0-50 \mathrm{BP})$, medium $(50-300 \mathrm{BP})$, old $(300-2000 \mathrm{BP})$, and ancient (2000-5500 BP) (Hinkel et al., 2003; Bockheim et al., 2004). In addition, we examined an erosional landscape remnant with deep organic deposits that is about 9000 years old (Eisner et al., 2005).

Soils of the Barrow region have been mapped at a scale of 1:20000 (Drew, 1957; Bockheim et al., 1999, 2002) and 
TABLE 1. Criteria for delineating the transient layer in permafrost-affected soils.

\begin{tabular}{|c|c|c|}
\hline Criterion & Explanation & References \\
\hline Location & Between active layer and permafrost & Yanovksy, 1933; Shur, 1988a, b \\
\hline Ice content & High ice content but commonly lower than ice-rich permafrost & Brown, 1965a, 1967a; Mackay, 1972; Pollard and French, 1980 \\
\hline Ice form & Ice-rich lens and boxes & Shur, 1988a, b; Hoefle et al., 1998 \\
\hline \multirow[t]{4}{*}{ Soil properties } & Intensive cryoturbation & Douglas and Tedrow, 1960; Hoefle et al., 1998 \\
\hline & Admixed subsoil organic matter & Brown, 1965a \\
\hline & Platy structure from lens ice & Tarnocai, 1994; Hoefle et al., 1998 \\
\hline & Soil moisture higher than in active layer & Tarnocai, 1983 \\
\hline
\end{tabular}

include 12 subgroups, four of which are classified as Turbels (Turbic Cryosols), four as Orthels (Static Cryosols), and four as Histels (Organic Cryosols) in the soil classification systems of the United States (Soil Survey Staff, 1999) and Canada (Soil Classification Working Group, 1998). Ice-wedge polygonal ground, which is common throughout the study areas, covers about $65 \%$ of the surface in the Barrow region (Brown, 1967b). The volume of segregation ice in pores and lenses averages $50 \%$ to $75 \%$ in the upper $2 \mathrm{~m}$ in the Barrow region (Sellman et al., 1975), but ice wedges may contribute an additional $10 \%$ to $20 \%$ to the volume in the upper $2 \mathrm{~m}$.

\section{METHODS AND MATERIALS}

A total of 138 pedons were obtained from sites representing major plant-community types and soil taxa in the Barrow area. Cores were collected in winter, when the wet, remote sites became accessible to heavy coring equipment transported by snow machine. Cores were collected to a depth of at least $1 \mathrm{~m}$ using a Little Beaver or Big Beaver drill equipped with a SIPRE core barrel $(7.5 \mathrm{~cm}$ inside diameter). Cores were described according to soil horizon, and the amount and type of segregation and vein ice (Shur and Ping, 1994) were estimated visually. All samples were dried at $70^{\circ} \mathrm{C}$, and the moisture content and bulk density were determined.

Oven-dried samples were ground to pass a $0.5 \mathrm{~mm}$ screen, and sub-samples were analyzed at the University of Wisconsin using a Dohrmann DC-190 total organic C analyzer (Tekmar-Dohrmann, Mason, $\mathrm{OH}$ ). Core samples from Barrow did not react with $1 \mathrm{M} \mathrm{HCl}$ and were therefore judged not to contain inorganic $\mathrm{C}$. The transition zone was identified in each of the pedons according to the criteria listed in Table 1.

\section{RESULTS}

\section{Field Identification of the Transition Zone}

Using the criteria listed in Table 1, we were able to detect the surface of the transition zone in $78 \%$ of the pedons analyzed (Table 2). For nine pedons (6.5\%), the field criteria were insufficient to identify the surface of the transition zone, and for 22 pedons $(15 \%)$ the presence of an ice wedge at depth made identification difficult. We were able to detect the lower boundary of the transition zone in $70 \%$ of the pedons (Table 2). In the case of 12 pedons (9\%), we had not cored deeply enough, and in 30 pedons $(22 \%)$ the field criteria were insufficient to locate the lower boundary.

The surface of the transition zone was detected at depths ranging from 20 to $55 \mathrm{~cm}$ below the ground surface, with an average depth of $34 \pm 7 \mathrm{~cm}$ (Table 2). The thickness ranged from 10 to $46 \mathrm{~cm}$ and averaged $23 \pm 8 \mathrm{~cm}$. The thickness of the active layer is inversely correlated with the thickness of the transition zone (adjusted $\mathrm{r}^{2}=0.23$; $p=0.029$ ), which is to be expected since they are the result of similar forcing factors, e.g., summer temperature. The transition zone was readily observable in moist acidic and wet tundra, but we were unable to delineate a transition zone in excessively drained soils on beach ridges. In the drained thaw-lake basins, there were no significant differences between age classes in the thickness of the transition zone or the locations of its upper and lower boundaries.

\section{Soil Properties of the Transition Zone}

Figure 1 is a schematic diagram showing the tripartite morphology of arctic soils. The transition zone is characterized by a cryoturbated horizon containing organic matter. Permafrost typically lacks cryoturbation to the same degree and has gleyed parent materials, or histic materials in the case of organic soils.

In the cores we examined, the transition zone often exhibited cryoturbation; abundant segregated ice in the form of lenses, veins, and a reticulate fabric; mixed organic matter in the form of patches, involutions, and layers; and a platy structure (Fig. 2). The platy structure is especially evident following melting of segregated lens ice (Fig. 2B). The transition zone in organic soils (Histels) could be readily determined from the ground-ice content and cryoturbation of organic fibers (Fig. 2E).

Analytical properties corroborating field evidence of a transition zone are illustrated in Figure 3. The transition zone generally has a greater amount of segregation ice and moisture content than the active layer, a greater amount of 
TABLE 2. Soil evidence for transient layer in drained thaw-lake basins of Arctic Alaska.

\begin{tabular}{|c|c|c|c|c|c|c|c|c|}
\hline \multirow[b]{2}{*}{$\begin{array}{l}\text { Pedon } \\
\text { No. }\end{array}$} & \multirow[b]{2}{*}{$\begin{array}{l}\text { Latitude } \\
\left({ }^{\circ} \mathrm{N}\right)\end{array}$} & \multirow[b]{2}{*}{$\begin{array}{l}\text { Longitude } \\
\left({ }^{\circ} \mathrm{W}\right)\end{array}$} & \multicolumn{6}{|c|}{ Transition layer } \\
\hline & & & $\begin{array}{c}\text { Surface } \\
(\mathrm{cm})\end{array}$ & $\begin{array}{l}\text { Bottom } \\
(\mathrm{cm})\end{array}$ & $\begin{array}{l}\text { Thickness } \\
(\mathrm{cm})\end{array}$ & $\begin{array}{c}\text { Soil } \\
\text { horizonation }\end{array}$ & $\begin{array}{c}\text { Ice } \\
\text { morphology }\end{array}$ & $\begin{array}{c}\text { Ice } \\
\text { content }(\%)\end{array}$ \\
\hline \multicolumn{9}{|c|}{ Young Age Class: } \\
\hline B3-1 & 71.2212 & 156.46310 & 46 & 62 & 16 & $\mathrm{Cg} /$ Oajjfm & $1, \mathrm{a}$ & 5 \\
\hline B3-2 & 71.2212 & 156.47113 & 38 & 72 & 34 & $\mathrm{Cg} / \mathrm{Oejjfm}$ & $1, \mathrm{v}$ & 20 \\
\hline B3-3 & 71.2212 & 156.47280 & 37 & 58 & 21 & $\mathrm{Cg} / \mathrm{Oajj} \mathrm{fm}$ & 1 & 40 \\
\hline B8-1 & 71.2113 & 156.52855 & 46 & 59 & 13 & $\mathrm{Cg} / \mathrm{Oajjfm}$ & 1 & 80 \\
\hline B8-2 & 71.2113 & 156.52966 & 38 & 57 & 19 & $\mathrm{Cg} /$ Oejjfm & $\mathrm{v}, 1$ & 15 \\
\hline B8-3 & 71.2113 & 156.53609 & 38 & 50 & 12 & $\mathrm{Cg} /$ Oejjfm & $1, \mathrm{v}$ & 75 \\
\hline B12-1 & 71.2648 & 156.66245 & 26 & $50 ?$ & & $\mathrm{Cg} / \mathrm{Oejj} \mathrm{fm}$ & 1 & 30 \\
\hline S8-02 & 71.21247 & 156.53564 & 29 & $?$ & & $\mathrm{Cg} / \mathrm{Oajj} \mathrm{fm}$ & $\mathrm{v}, 1$ & 20 \\
\hline S8-03 & 71.21242 & 156.53856 & 34 & $71+$ & $37+$ & $\mathrm{Cg} / \mathrm{Oajj} \mathrm{fm}$ & $\mathrm{v}, 1$ & 10 \\
\hline S8-04 & 71.2108 & 156.53114 & 30 & 55 & 25 & $\mathrm{Cg} / \mathrm{Oajj} \mathrm{fm}$ & $1, \mathrm{v}$ & 10 \\
\hline S8-05 & 71.21072 & 156.53531 & 30 & $61 ?$ & & $\mathrm{Cgfm}$ & nd & nd \\
\hline S8-06 & 71.21047 & 156.54069 & 32 & 67 & 35 & 2C/Oajjfm & $1, \mathrm{v}$ & 20 \\
\hline S8-07 & 71.20839 & 156.53072 & 29 & $51+$ & $22+$ & $2 \mathrm{Cg}$ & $1, \mathrm{v}$ & 5 \\
\hline S8-08 & 71.20844 & 156.53489 & 33 & $54+$ & $19+$ & $\mathrm{Cg} 2 \mathrm{f}$ & $\mathrm{v}, 1$ & 10 \\
\hline S8-10 & 71.20722 & 56.53469 & 30 & $41+$ & $11+$ & & & \\
\hline \multirow{3}{*}{ S8-11 } & 71.21353 & 156.53583 & 33 & $69+$ & $36+$ & $\mathrm{Cg} / \mathrm{Oajj} \mathrm{fm}$ & $\mathrm{v}$ & 5 \\
\hline & & Avg. & 34.3 & 60.0 & 21.9 & & & \\
\hline & & SD & 5.8 & 6.9 & 8.9 & & & \\
\hline \multicolumn{9}{|c|}{ Medium Age Class: } \\
\hline B $1-2$ & 71.2779 & 156.44985 & 37 & 55 & 18 & $\mathrm{Cg} /$ Oajjfm & $\mathrm{v}$ & 60 \\
\hline B1-3 & 71.2779 & 156.44791 & 48 & 74 & 26 & $\mathrm{Cg} / \mathrm{Oejj} \mathrm{fm}$ & $\mathrm{v}$ & 50 \\
\hline B1-4 & 71.2779 & 156.44265 & 32 & $?$ & & $\mathrm{Cg} / \mathrm{Oijjfm}$ & $1, \mathrm{v}, \mathrm{a}$ & 5 \\
\hline B9-1 & 71.2170 & 156.53988 & & 34 & & & w & \\
\hline B9-2 & 71.2170 & 156.54736 & 33 & 62 & 29 & $\mathrm{Cg} / \mathrm{Oijjfm}$ & 1 & 70 \\
\hline B9-3 & 71.2170 & 156.55540 & 31 & 51 & 20 & $\mathrm{Cg} / \mathrm{Oejj} \mathrm{fm}$ & $\mathrm{v}$ & 20 \\
\hline B10-1 & 71.2608 & 156.72194 & 36 & 56 & 20 & $\mathrm{Cg} / \mathrm{Oejifm}$ & $\mathrm{v}, 1$ & 40 \\
\hline B10-2 & 71.2608 & 156.72610 & 27 & 46 & 19 & $\mathrm{Cg} / \mathrm{Oejj} \mathrm{fm}$ & 1 & 40 \\
\hline B10-3 & 71.2608 & 156.73136 & 30 & 67 & 37 & $\mathrm{Cg} / \mathrm{Oejj} \mathrm{fm}$ & $1, \mathrm{v}$ & 50 \\
\hline B10-4 & 71.2608 & 156.74022 & 40 & 50 & 10 & $\mathrm{Cg} /$ Oejjfm & 1 & 15 \\
\hline B10-5 & 71.2608 & 156.74438 & 40 & 56 & 16 & $\mathrm{Cg} / \mathrm{Oejj} \mathrm{fm}$ & $\mathrm{a}$ & 10 \\
\hline VB-21 & 70.0800 & 156.29025 & 28 & 52 & 24 & $\mathrm{Cg} / \mathrm{Oajjfm}$ & nd & nd \\
\hline S1-01 & 71.28664 & 156.44345 & 28 & 51 & 23 & $\mathrm{Cg} / \mathrm{Oejj} \mathrm{fm}$ & $1, \mathrm{v}$ & 5 \\
\hline S1-02 & 71.28628 & 156.44839 & $?$ & 50 & & $\mathrm{Cg} /$ Oajjfm & $1, \mathrm{v}$ & 3 \\
\hline S1-03 & 71.28594 & 156.45170 & 27 & $54 ?$ & & $\mathrm{Cg} / \mathrm{O}$ ajjfm & $1, \mathrm{v}$ & 8 \\
\hline S1-04 & 71.27931 & 156.43961 & 44 & $?$ & & $\mathrm{Cg} / \mathrm{Oajj} \mathrm{fm}$ & $\mathrm{v}$ & \\
\hline S1-05 & 71.27922 & 156.44381 & 35 & 72 & 37 & $\mathrm{Cg} / \mathrm{Oajjfm}$ & 1 & 3 \\
\hline S1-06 & 71.27914 & 156.44880 & 25 & 55 & 30 & $\mathrm{Cg} / \mathrm{Oijjfm}$ & $1, \mathrm{v}$ & 30 \\
\hline S1-07 & 71.27236 & 156.43628 & 23 & 40 & 17 & $\mathrm{Cg} /$ Oejjfm & $1, \mathrm{v}$ & 50 \\
\hline S1-08 & 71.27228 & 156.44047 & 23 & $56+$ & $33+$ & Oajj/Cgfm & $\mathrm{v}, 1$ & 70 \\
\hline S1-09 & 71.27219 & 156.44589 & 33 & 60 & 27 & Oejj/Cgfm & a & 15 \\
\hline $\mathrm{S} 1-10$ & 71.27081 & 156.44019 & 26 & 48 & 22 & $\mathrm{Cg} / \mathrm{Oejjfm}$ & a & nd \\
\hline S1-11 & 71.28764 & 156.44739 & 26 & 45 & 19 & $\mathrm{Cg} / \mathrm{Oajj} \mathrm{fm}$ & 1 & 10 \\
\hline $\mathrm{S} 1-12$ & 71.27931 & 156.43961 & 25 & 40 & 15 & Oajj/Cgfm & $1, \mathrm{v}$ & 15 \\
\hline KV1-01 & 71.16400 & 156.70400 & 36 & $?$ & & $\mathrm{Cg} /$ Oejjfm & $\mathrm{v}, 1$ & 5 \\
\hline KV1-02 & 71.16300 & 156.70000 & 39 & 52 & 13 & $\mathrm{Cg} /$ Oejifm & $\mathrm{v}, 1$ & 5 \\
\hline KV1-03 & 71.16200 & 156.70500 & ? & ? & & $\mathrm{Cg} / \mathrm{Oejj} f \mathrm{fm}$ & $1, \mathrm{v}$ & 10 \\
\hline LL-01 & & & 38 & 60 & 22 & Cg/Oajjfm & $\mathrm{v}, \mathrm{a}, \mathrm{l}$ & 50 \\
\hline LL-02 & 71.24800 & 156.25100 & 30 & $42+$ & $12+$ & $\mathrm{Cg} / \mathrm{Oijjfm}$ & $\mathrm{a}$ & 40 \\
\hline LL-03 & 71.24200 & 156.25200 & & 42 & & & $\mathrm{w}$ & 20 \\
\hline VB14-01 & 71.18400 & 156.85500 & 27 & 47 & 20 & $\mathrm{Cg} /$ Oejjfm & $1, \mathrm{v}$ & 20 \\
\hline VB14-02 & 71.18000 & 156.85300 & 34 & $53 ?$ & & $\mathrm{Cg} / \mathrm{Oejj} \mathrm{fm}$ & 1 & 35 \\
\hline \multirow[t]{3}{*}{ VB14-03 } & 71.17800 & 156.84900 & 33 & $51 ?$ & & $\mathrm{Cg} /$ Oejjfm & 1 & 15 \\
\hline & & Avg. & 32.2 & 52.7 & 22.1 & & & \\
\hline & & SD & 6.4 & 9.8 & 7.0 & & & Table 2 continued: \\
\hline
\end{tabular}

organic carbon than the near-surface permafrost, and a bulk density intermediate between those of the active layer and the permafrost. The active layer normally has a high bulk density in the lower part from transfer of moisture to the surface during seasonal thawing (Mackay, 1980; Smith et al., 1991; Tarnocai, 1994) and to the transition zone during episodic deep thawing. Permafrost has a low bulk density from ice enrichment.

\section{DISCUSSION}

Delineation of the Transition Zone in Arctic Soils

We were able to recognize the transition zone from soil cores collected during winter, primarily from the amount and form of segregated and vein ice. The visible ice content is greater in the transition zone than in the active 
TABLE 2. Soil evidence for transient layer in drained thaw-lake basins of Arctic Alaska - continued:

\begin{tabular}{|c|c|c|c|c|c|c|c|c|}
\hline \multirow[b]{2}{*}{$\begin{array}{l}\text { Pedon } \\
\text { No. }\end{array}$} & \multirow[b]{2}{*}{$\begin{array}{l}\text { Latitude } \\
\left({ }^{\circ} \mathrm{N}\right)\end{array}$} & \multirow[b]{2}{*}{$\begin{array}{l}\text { Longitude } \\
\left({ }^{\circ} \mathrm{W}\right)\end{array}$} & \multicolumn{6}{|c|}{ Transition layer } \\
\hline & & & $\begin{array}{l}\text { Surface } \\
(\mathrm{cm})\end{array}$ & $\begin{array}{l}\text { Bottom } \\
(\mathrm{cm})\end{array}$ & $\begin{array}{l}\text { Thickness } \\
(\mathrm{cm})\end{array}$ & $\begin{array}{c}\text { Soil } \\
\text { horizonation }\end{array}$ & $\begin{array}{c}\text { Ice } \\
\text { morphology }\end{array}$ & $\begin{array}{c}\text { Ice } \\
\text { content }(\%)\end{array}$ \\
\hline \multicolumn{9}{|c|}{ Old Age Class: } \\
\hline B2-1 & 71.2725 & 156.48281 & 43 & 66 & 23 & $\mathrm{Cg} / \mathrm{Oijjfm}$ & 1 & 10 \\
\hline B2-2 & 71.2725 & 156.47616 & 42 & 66 & 24 & $\mathrm{Cg} / \mathrm{Oajifm}$ & 1 & 60 \\
\hline B2-3 & 71.2725 & 156.48558 & 40 & $50 ?$ & & $\mathrm{Cg} / \mathrm{Oajjfm}$ & $\mathrm{v}, \mathrm{a}$ & 10 \\
\hline B4-1 & 71.2133 & 156.47961 & 44 & 64 & 20 & $\mathrm{Cg} / \mathrm{Oejifm}$ & $1, \mathrm{v}$ & 40 \\
\hline B4-2 & 71.2133 & 156.48764 & 39 & 76 & 37 & $\mathrm{Cg} / \mathrm{O} a \mathrm{jifm}$ & $1, \mathrm{v}$ & 40 \\
\hline B4-3 & 71.2133 & 156.49457 & 35 & 48 & 13 & $\mathrm{Cg} / \mathrm{O} a \mathrm{jjfm}$ & $1, \mathrm{v}$ & 60 \\
\hline B6-1 & 71.2093 & 156.51553 & 37 & 62 & 25 & $\mathrm{Cg} / \mathrm{Oejifm}$ & $1, \mathrm{v}$ & 60 \\
\hline B6-2 & 71.2093 & 156.52080 & 52 & 78 & 25 & $\mathrm{Cg} / \mathrm{Oejjfm}$ & $1, \mathrm{v}$ & 50 \\
\hline B6-3 & 71.2093 & 156.52246 & 33 & 49 & 16 & Oeffj/Cgfm & 1 & 90 \\
\hline B11-1 & 71.2535 & 156.67254 & 46 & 68 & 22 & $\mathrm{Cg} /$ Oejjfm & $1, \mathrm{v}$ & 50 \\
\hline B11-2 & 71.2535 & 156.67919 & 35 & 62 & 27 & $\mathrm{Cg} / \mathrm{Oajjfm}$ & $1, \mathrm{v}$ & 85 \\
\hline B11-3 & 71.2535 & 156.68085 & 42 & 55 & 13 & $\mathrm{Cg} / \mathrm{Oajifm}$ & $1, \mathrm{v}$ & 30 \\
\hline B11-4 & 71.2535 & 156.68805 & 40 & 67 & 23 & $\mathrm{Cg} / \mathrm{Oijjfm}$ & 1 & 70 \\
\hline VB-15 & 71.16742 & 156.84567 & 30 & 57 & 27 & $\mathrm{Cg} / \mathrm{Oejifm}$ & nd & nd \\
\hline VB-27 & 70.97317 & 156.00761 & & 30 & & & w & nd \\
\hline S6-02 & 71.21200 & 156.51800 & 35 & 55 & 20 & $\mathrm{Cgfm}$ & $\mathrm{v}, 1, \mathrm{a}$ & 15 \\
\hline S6-03 & 71.21164 & 156.52170 & 45 & $50+$ & $5+$ & $\mathrm{Cg} / \mathrm{O}$ ajjfm & $\mathrm{v}, 1$ & 5 \\
\hline S6-04 & 71.21009 & 156.51180 & 29 & 63 & 34 & $\mathrm{Cg} /$ Oefm & 1 & 5 \\
\hline S6-05 & 71.20972 & 156.51633 & 29 & 49 & 20 & Oaji/Cgfm & 1 & 30 \\
\hline S6-06 & 71.20925 & 156.52041 & 33 & 51 & 18 & $\mathrm{Cg} / \mathrm{O} a \mathrm{jjfm}$ & $\mathrm{v}, 1$ & 5 \\
\hline S6-07 & 71.2082 & 156.51189 & 23 & 45 & 22 & $\mathrm{Cg} / \mathrm{O} a \mathrm{jifm}$ & $1, \mathrm{v}$ & 45 \\
\hline S6-08 & 71.20786 & 156.51517 & 28 & $54+$ & $26+$ & Oajj/Cgfm & $1, \mathrm{v}$ & 5 \\
\hline S6-09 & 71.20767 & 156.51889 & 27 & 55 & 28 & $\mathrm{Cg} / \mathrm{Oejjfm}$ & $\mathrm{a}$ & 75 \\
\hline S6-10 & 71.20667 & 156.51411 & 55 & 70 & 15 & $\mathrm{Cg} / \mathrm{O} a \mathrm{jjfm}$ & $1, \mathrm{v}$ & 5 \\
\hline S6-11 & 71.21303 & 156.51944 & 34 & $64+$ & $30+$ & Oejj/Cgfm & 1 & 40 \\
\hline TC-01 & 71.25596 & 156.34412 & 39 & $57 ?$ & & $\mathrm{Cg} / \mathrm{Oejifm}$ & a & 60 \\
\hline TC-02 & 71.25595 & 156.34900 & $?$ & $?$ & & $\mathrm{Cg} / \mathrm{Oejjfm}$ & 1 & 15 \\
\hline TC-03 & 71.25594 & 156.35289 & $?$ & $?$ & & $\mathrm{Cg} / \mathrm{Oejifm}$ & a & 10 \\
\hline TC-04 & 71.25100 & 156.34200 & ? & ? & & $\mathrm{Cg} / \mathrm{Oejjfm}$ & 1 & 40 \\
\hline TC-05 & 71.25089 & 156.34637 & & 40 & & & w & \\
\hline TC-06 & 71.25116 & 156.34998 & 20 & $43 ?$ & & $\mathrm{Cg} / \mathrm{O} a \mathrm{jjfm}$ & $\mathrm{a}$ & 60 \\
\hline TC-07 & 71.24519 & 156.33955 & 43 & ? & & $\mathrm{Cg} / \mathrm{Oejjfm}$ & 1 & 60 \\
\hline TC-08 & 71.24629 & 156.34444 & & 44 & & & $\mathrm{w}$ & \\
\hline TC-09 & 71.24559 & 156.34979 & & 33 & & & $\mathrm{w}$ & \\
\hline TC-10 & 71.24253 & 156.33925 & $?$ & ? & & $\mathrm{Cg} / \mathrm{Oijj} \mathrm{fm}$ & $\mathrm{a}$ & nd \\
\hline TC-11 & 71.25818 & 156.34785 & ? & 57 & & Oejj/Cgfm & 1 & 20 \\
\hline \multirow[t]{3}{*}{ TC-12 } & 71.24519 & 156.33955 & 39 & 54 & 15 & $\mathrm{Cg} /$ Oejjfm & 1 & 50 \\
\hline & & Avg. & 37.0 & 56.3 & 22.2 & & & \\
\hline & & SD & 8.1 & 12.1 & 6.3 & & & \\
\hline \multicolumn{9}{|c|}{ Ancient Age Class: } \\
\hline B5-1 & 71.2212 & 156.51020 & 42 & 54 & 12 & $\mathrm{Cg} / \mathrm{Oajjfm}$ & $\mathrm{v}, 1$ & 30 \\
\hline B5-2 & 71.2212 & 156.51297 & 42 & 52 & 10 & $\mathrm{Cg} / \mathrm{Oejjfm}$ & $\mathrm{v}, 1$ & 50 \\
\hline B5-3 & 71.2212 & 156.51602 & 35 & 56 & 21 & $\mathrm{Cg} / \mathrm{Oejjfm}$ & $\mathrm{a}, 1$ & 30 \\
\hline B7-1 & 71.2030 & 156.52161 & & 36 & & & $\mathrm{w}$ & \\
\hline B7-2 & 71.2030 & 156.52787 & 42 & 62 & 20 & $\mathrm{Cg} / \mathrm{Oejjfm}$ & $1, \mathrm{v}$ & 60 \\
\hline B7-3 & 71.2030 & 156.53330 & 36 & 54 & 18 & $\mathrm{Cg} / \mathrm{Oajjfm}$ & $1, \mathrm{v}$ & 80 \\
\hline VB-13 & 71.13437 & 156.95825 & 30 & 67 & 37 & $\mathrm{Cg} / \mathrm{Oejjfm}$ & 1 & nd \\
\hline VB-18 & 71.16053 & 156.56042 & 27 & 56 & 29 & $\mathrm{Cg} / \mathrm{Oejjfm}$ & nd & nd \\
\hline VB-19 & 71.14028 & 156.56042 & 31 & 49 & 18 & $\mathrm{Cg} / \mathrm{Oejjfm}$ & nd & nd \\
\hline VB-33 & 71.13617 & 155.66039 & 30 & 54 & 24 & & 1 & nd \\
\hline S7-01 & 71.20458 & 156.52500 & 33 & 59 & 26 & Oefm & nd & nd \\
\hline S7-02 & 71.2045 & 156.52958 & 30 & 55 & 25 & Oafm & 1 & 10 \\
\hline S7-03 & 71.20441 & 156.53375 & & 28 & & & w & \\
\hline S7-04 & 71.20311 & 156.52434 & 33 & 56 & 23 & $\mathrm{Cg} /$ Oejjfm & $\mathrm{v}, 1$ & 5 \\
\hline S7-05 & 71.20303 & 156.52934 & 35 & 54 & 19 & Oajj/Cgfm & 1 & 10 \\
\hline S7-06 & 71.20295 & 156.53350 & & 40 & & & $\mathrm{w}$ & \\
\hline S7-07 & 71.2008 & 156.52517 & & 35 & & & $\mathrm{w}$ & \\
\hline S7-08 & 71.20075 & 156.52892 & & 37 & & & w & \\
\hline S7-09 & 71.20056 & 156.53222 & & 48 & & & $\mathrm{w}$ & \\
\hline S7-10 & 71.19967 & 156.52872 & 40 & $?$ & & Wf1, Oafm & $\mathrm{i}$ & 100 \\
\hline S7-11 & 71.20544 & 156.52975 & & 35 & & & w & \\
\hline \multirow{3}{*}{ S7-12 } & 71.2045 & 156.52958 & 33 & 54 & 21 & $\mathrm{Cg} / \mathrm{Oejjfm}$ & & \\
\hline & & Avg. & 34.6 & 49.6 & 21.6 & & & \\
\hline & & SD & 4.9 & 10.3 & 6.8 & & & \\
\hline
\end{tabular}


TABLE 2. Soil evidence for transient layer in drained thaw-lake basins of Arctic Alaska - continued:

\begin{tabular}{|c|c|c|c|c|c|c|c|c|}
\hline \multirow[b]{2}{*}{$\begin{array}{l}\text { Pedon } \\
\text { No. }\end{array}$} & \multirow[b]{2}{*}{$\begin{array}{l}\text { Latitude } \\
\left({ }^{\circ} \mathrm{N}\right)\end{array}$} & \multirow[b]{2}{*}{$\begin{array}{l}\text { Longitude } \\
\left({ }^{\circ} \mathrm{W}\right)\end{array}$} & \multicolumn{6}{|c|}{ Transition layer } \\
\hline & & & $\begin{array}{l}\text { Surface } \\
(\mathrm{cm})\end{array}$ & $\begin{array}{c}\text { Bottom } \\
(\mathrm{cm})\end{array}$ & $\begin{array}{c}\text { Thickness } \\
(\mathrm{cm})\end{array}$ & $\begin{array}{c}\text { Soil } \\
\text { horizonation }\end{array}$ & $\begin{array}{c}\text { Ice } \\
\text { morphology } y^{1}\end{array}$ & $\begin{array}{c}\text { Ice } \\
\text { content }(\%)\end{array}$ \\
\hline \multicolumn{9}{|c|}{ Erosional Remnant: } \\
\hline PPP02-01 & 71.06875 & 156.40604 & 20 & 56 & 46 & Wf1 & $\mathrm{w}$ & \\
\hline PPP02-02 & 71.06875 & 156.40604 & 22 & 41 & 19 & & $\mathrm{w}$ & \\
\hline PPP02-03 & 71.06875 & 156.40604 & & 37 & & & $\mathrm{w}$ & \\
\hline PPP02-04 & 71.06875 & 156.40604 & ? & ? & & Oafm & nd & nd \\
\hline PPP02-05 & 71.06875 & 156.40604 & 37 & $64+$ & $27+$ & Oafm, Oa/Wf & $1, \mathrm{v}$ & 20 \\
\hline PPP-01 & 71.05700 & 156.38300 & & 62 & & $\mathrm{Cg} / \mathrm{Oajj} \mathrm{fm}$ & $\mathrm{w}$ & nd \\
\hline PPP-02 & 71.06500 & 156.40300 & & 52 & & Oejj/Cgfm & $\mathrm{w}$ & nd \\
\hline \multirow[t]{3}{*}{ PPP-03 } & 71.07600 & 156.42600 & & 58 & & Oajj/Cgfm & $\mathrm{w}$ & nd \\
\hline & & Avg. & 26.3 & 51.0 & 32.5 & & & \\
\hline & & SD & 9.3 & 9.9 & 19.1 & & & \\
\hline \multicolumn{9}{|c|}{ Age Class Not Known: } \\
\hline R1-02 & 71.06875 & 156.40604 & 32 & $58 ?$ & & Oajj/Cgfm & $\mathrm{v}$ & 12 \\
\hline $\mathrm{R} 2-02$ & 70.15035 & 157.11797 & 29 & $?$ & & Oejj/Cgfm & $1, \mathrm{v}$ & 5 \\
\hline R3-02 & 70.00227 & 156.7132 & 38 & 79 & 41 & $\mathrm{Cg} / \mathrm{Oejj} \mathrm{fm}$ & $\mathrm{a}, 1$ & 20 \\
\hline BIE-02 & 71.00227 & 156.7132 & 22 & 58 & 36 & Oafm & $\mathrm{v}$ & 30 \\
\hline BIW1 & & & 24 & 56 & 32 & Abf & nd & nd \\
\hline NS1-01 & 71.02920 & 156.61000 & & 32 & & $\mathrm{Cg} /$ Oajjfm & $\mathrm{w}$ & \\
\hline NS1-02 & 71.02920 & 156.60991 & 35 & ? & & $\mathrm{Cg} / \mathrm{Oajjfm}$ & $1, \mathrm{v}$ & 15 \\
\hline NS1-03 & 71.09000 & 156.61400 & 33 & $53+$ & $20+$ & $\mathrm{Cg} / \mathrm{Oejj} \mathrm{fm}$ & nd & nd \\
\hline NS1-04 & 71.09000 & 156.61400 & $?$ & $?$ & & $\mathrm{Cg} / \mathrm{Oajjfm}$ & nd & nd \\
\hline SLL-01 & 71.21400 & 156.61900 & 38 & ? & & $\mathrm{Cg} / \mathrm{Oajj} \mathrm{fm}$ & 1 & 10 \\
\hline SLL-02 & 71.21300 & 156.61000 & 30 & 45 & 15 & $\mathrm{Cg} / \mathrm{Oajj} \mathrm{fm}$ & nd & nd \\
\hline TR-1 & 71.06900 & 156.55900 & & 56 & & $\mathrm{Cg} / \mathrm{Oajj} \mathrm{fm}$ & w & nd \\
\hline TR-2 & 71.06600 & 156.55800 & & 76 & & $\mathrm{Cg} / \mathrm{Oajjfm}$ & $\mathrm{W}$ & \\
\hline DPD-03-01 & 70.43788 & 156.42450 & 30 & 48 & 18 & Oajj/Cgfm & 1 & nd \\
\hline DPD-03-02 & 70.43788 & 156.42450 & & 30 & & $\mathrm{Cg} /$ Oajjfm & $\mathrm{w}$ & nd \\
\hline WID-03-01 & 70.4325 & 156.36250 & 20 & $?$ & & $\mathrm{Cg} /$ Oajjfm & nd & nd \\
\hline WIR-03-01 & 70.46417 & 156.48888 & 22 & ? & & $\mathrm{Cg} 2 \mathrm{f}$ & nd & nd \\
\hline BH3-03-01 & 70.47694 & 156.48555 & 51 & 85 & 36 & Oafm & 1 & nd \\
\hline SGD-03-01 & 70.43855 & 156.33005 & 25 & $?$ & & Oef & 1 & nd \\
\hline DRF-03-01 & 70.46811 & 156.34811 & 40 & $64 ?$ & & $\mathrm{Cg} /$ Oajjfm & nd & nd \\
\hline RBD-03-01 & 70.45200 & 156.27747 & 40 & ? & & Oef & nd & nd \\
\hline
\end{tabular}

${ }^{1}$ Transient ice morphology: $1=$ lens, $\mathrm{v}=$ vein, $\mathrm{a}=$ ataxitic, $\mathrm{w}=\mathrm{ice}$ wedge, $\mathrm{nd}=$ not determined.

layer because of downward moisture migration from the overlying active layer and subsequent refreezing (Mackay, 1983; Hinkel et al., 1996, 2001). This phenomenon is manifested by the presence of ice veins and ice lenses that can range from a few $\mathrm{mm}$ to $30 \mathrm{~cm}$ in thickness, which may represent injection ice rather than segregation ice. Veins can extend from the active layer well into the permafrost.

Cryoturbation occurs not only in the active layer, but also in the transition zone during episodic deep thaw events. Although there is some debate in the literature as to the mechanism of cryoturbation, the predominant mechanisms appear to be differential frost heave, load casting, and convection (Mackay, 1980; Van Vliet-Lanoë, 1991).

The transition zone generally contains organic matter in the subsoil in the form of patches, involutions, and layers. Douglas and Tedrow (1960:296) noted that "the zone of organic concentration is usually well within the permafrost and is not affected by present-day pedologic processes." There has been considerable debate in the soils literature regarding the origin of this organic matter. Four proposed mechanisms include (1) cryoturbation (Douglas and Tedrow, 1960; Brown, 1965a, b); (2) burial by more recent sediments such as loess, dune sand, or glacial deposits (Everett, 1979); (3) recycling of organic matter during the thaw-lake cycle (Brown et al., 1980); and (4) material falling into ground cracks during winter contraction episodes (Lachenbruch, 1962).

We favor cryoturbation during episodes of deep thawing as the primary mechanism for the existence of organic matter in the transition zone because (1) the organic matter is ubiquitous in soils of the mid-Arctic with differing histories that do not require burial or operation of the thaw-lake cycle; and (2) the subsoil organic matter is most commonly dated to the last 5000 years, when the climate was colder and cryoturbation was active (Douglas and Tedrow, 1960; Brown, 1965a, 1969; Tarnocai and Zoltai, 1978; Eisner et al., 2005).

Because of the accumulation of segregated ice and organic matter, the transition zone often has greater water content than the active layer. Tarnocai (1972) reported that the field moisture content of what could be considered the transient layer was on average $80 \%$ greater on a mass basis than that in the active layer. The lower part of the active layer often has a massive soil structure with a high bulk density (Tarnocai, 1983, 1994).

The lower boundary of the transition zone represents the maximum depth of thaw during episodic warm events 


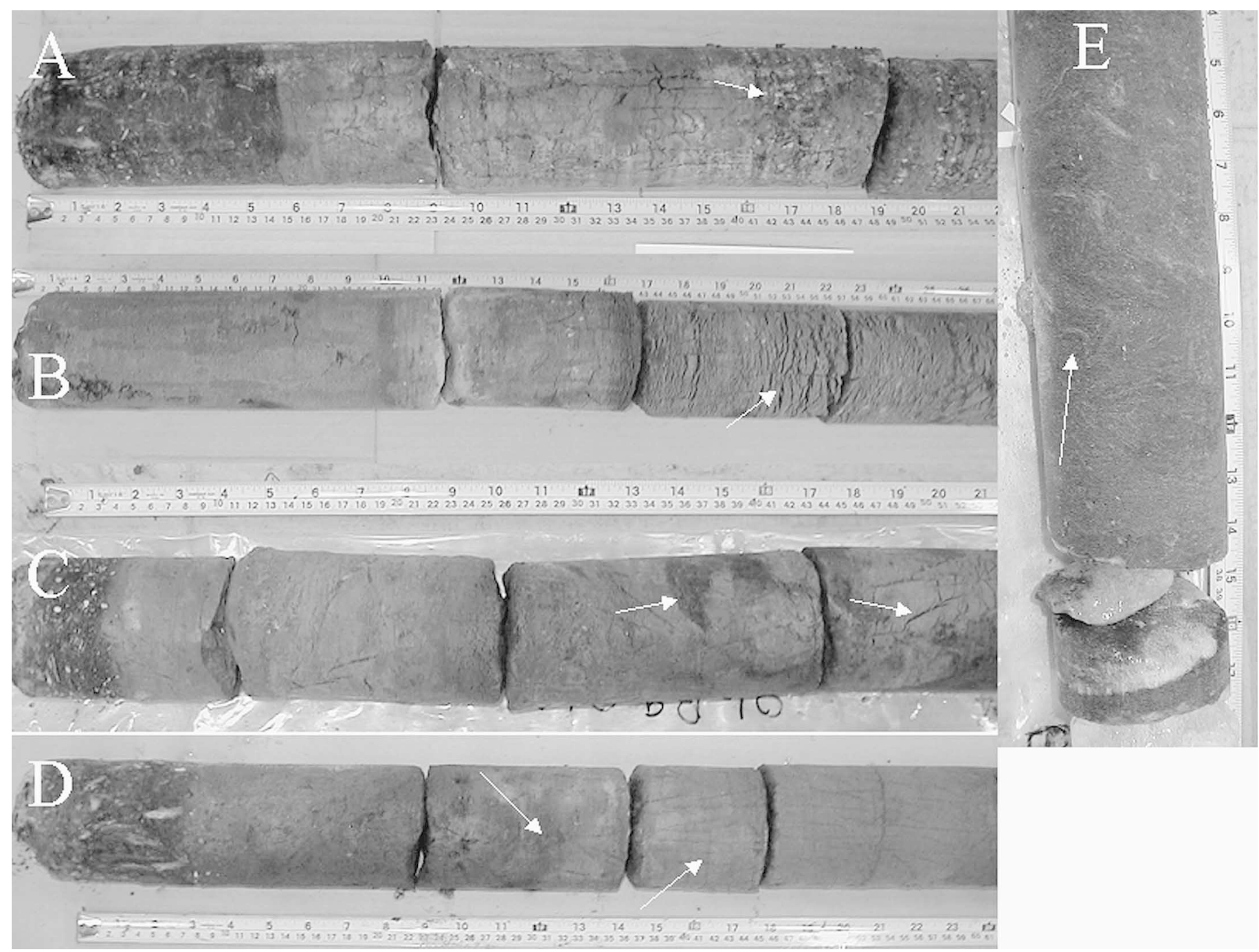

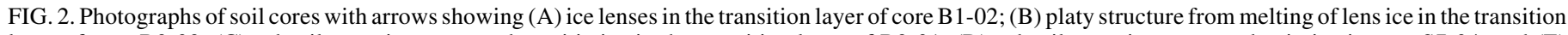

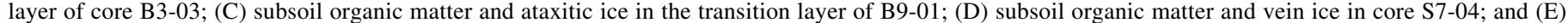

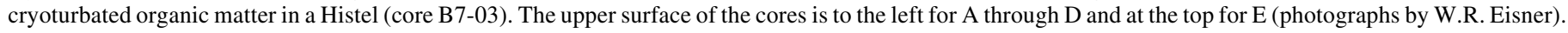

(Shur, 1988a, b; Shur et al., 2005). During warmer periods, soil processes such as cryoturbation and leaching may operate at greater depths than during "normal" years. Many cryopedologists have attributed the encasement of organic matter in the near-surface permafrost to periods of greater warming (Douglas and Tedrow, 1960; Brown, 1965b; Shur and Ping, 1994; Hoefle et al., 1998). The fact that there were no significant differences in the boundaries and thickness of the transition zone in drained thaw-lake basins ranging from several hundred to 5500 years in age confirms that the transition zone may form within a subdecadal to multi-centennial time frame (Shur et al., 2005).

\section{Implications of the Transition Zone in Soil Development}

Shur (1988a, b) and Shur et al. (2005) demonstrated that the transition zone acts as a buffer between the active layer and the consistently frozen permafrost. During warm years, the transition zone protects the permafrost from thaw by not meeting the latent heat requirements. However, during unusually warm summers with deep thaw penetration, ground ice can melt and cause ground surface subsidence. Shur also suggested that the transition zone is useful for predicting the long-term (decadal to millennial) changes in thickness of the active layer.

The transition zone is particularly important for understanding the development of Arctic soils. Observations of well-developed soil properties in the upper part of the permafrost can only be explained by the presence of a transition layer (Shur and Ping, 1994; Hoefle et al., 1998). It is therefore essential that soil investigations be extended well into the frozen layer to detect the full extent of pedogenesis. In that permafrost restricts the downward movement of weathering products, Gelisols are ideal for the determination of gains and losses in soil mass and volume (Munroe and Bockheim, 2001). Kokelj and Burn (2005) observed solute enrichment in near-surface permafrost, i.e., in what we identify as the transition zone. Mean concentrations of $\mathrm{Ca}^{2+}$ and $\mathrm{Mg}^{2+}$ were up to 7.5 times greater than those in the active layer. Admixed organic 

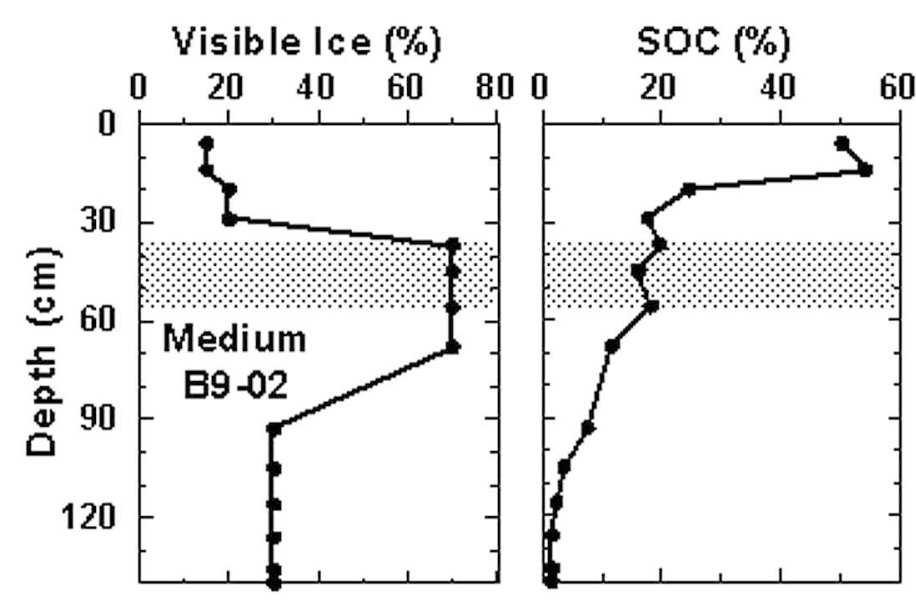

Soil Moisture (\%)

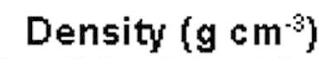
60
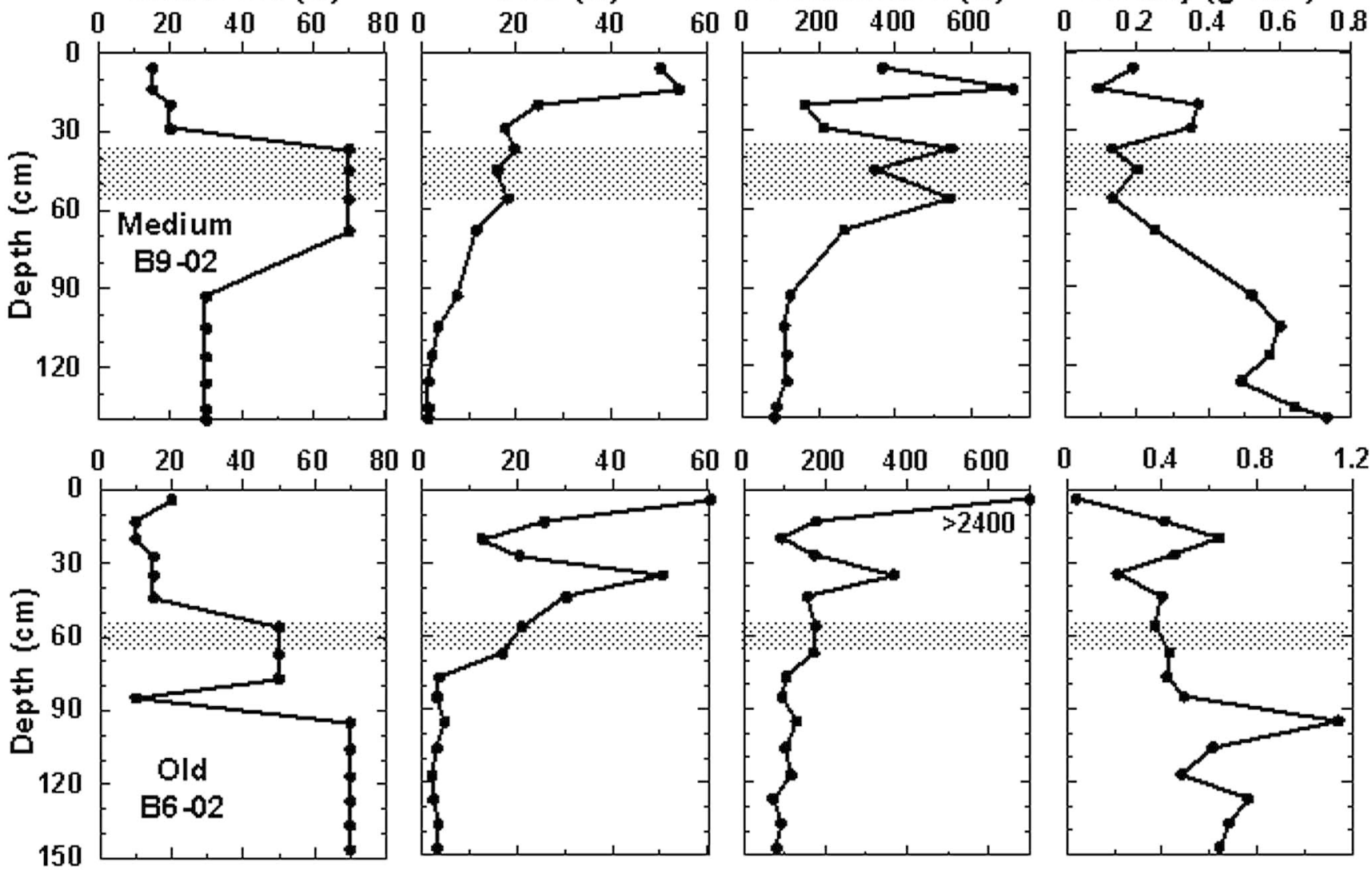

$00 \quad 200 \quad 400 \quad 600$
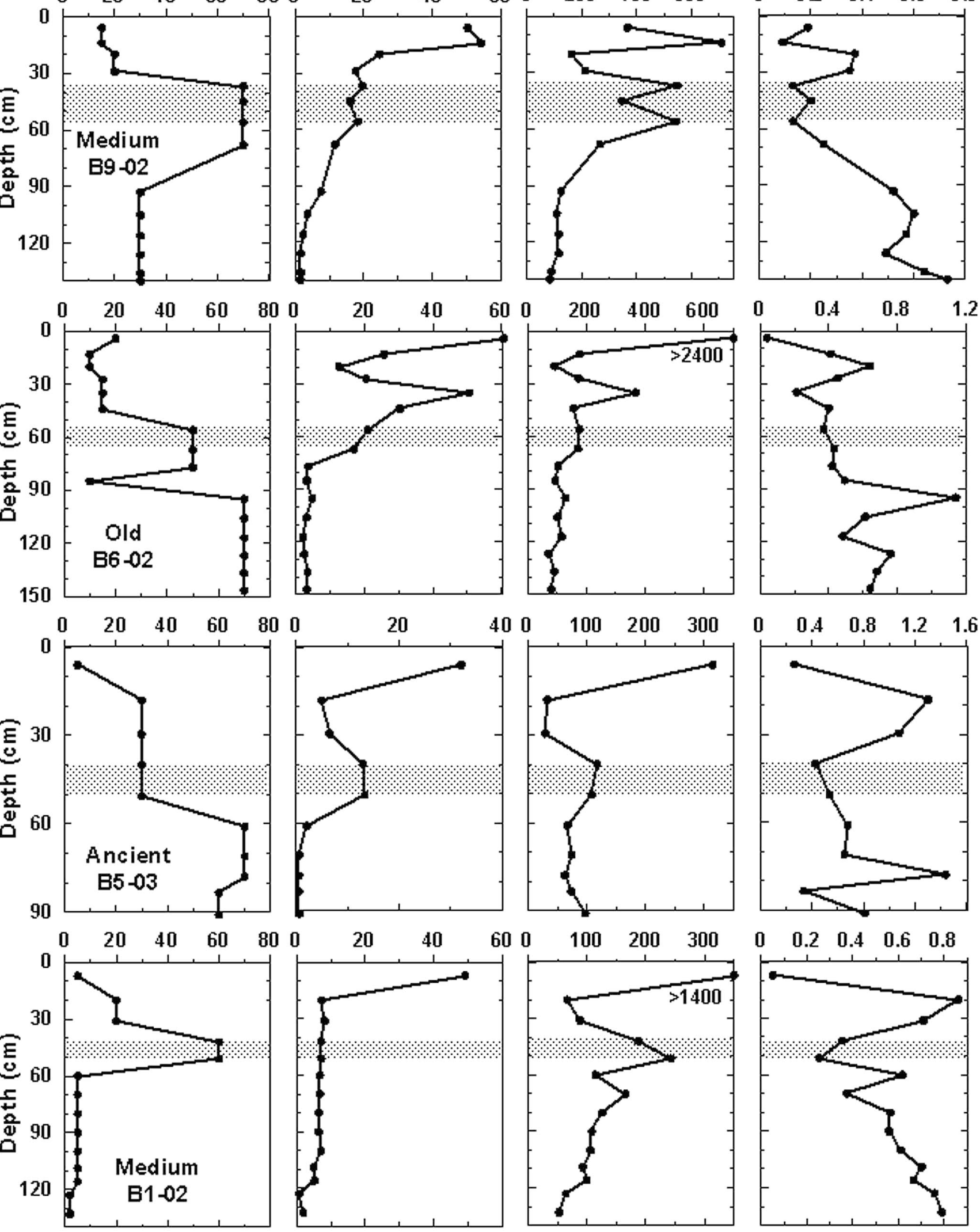

FIG. 3. Depth distribution of visible segregated ice, organic carbon, soil moisture content, and bulk density from cores collected in four drained thaw-lake basins of medium, old, and ancient age classes. The shaded area represents the transition zone. 
matter in the transition zone can be radiocarbon-dated (Brown, 1965a, b; Tarnocai and Zoltai, 1978; Zoltai et al., 1978), and fossil pollen can be recovered from these layers for paleoclimatic reconstruction (Eisner et al., 2005). Cryoturbation processes are important in environmental reconstruction (Van Vliet-Lanoë, 1988).

\section{CONCLUSIONS}

The transition layer is found beneath the active layer. Although it is the uppermost portion of the permafrost, it experiences episodic thaw over time periods ranging from sub-decadal to multi-centennial. Because of these thawing episodes, it has properties that differ from those of the underlying permafrost. We were able to detect the transition layer in approximately two-thirds of the 138 pedons sampled near Barrow, Alaska. Identification was primarily based on the occurrence of cryoturbation and redistributed organic carbon below the contemporary active layer, an abundance of segregated ice as lenses and veins forming a net-like structure, and a higher amount of soil moisture than in the overlying active layer. The surface of the transition layer was detected at depths ranging from 20 to $55 \mathrm{~cm}$, with an average depth of $34 \pm 7 \mathrm{~cm}$. The thickness of the layer ranged from 10 to $46 \mathrm{~cm}$ and averaged $23 \pm 8 \mathrm{~cm}$. A fuller understanding of pedogenic processes in permafrost-affected soils can be gained by considering these soils within the framework of a threelayer conceptual model.

\section{ACKNOWLEDGEMENTS}

This work was supported by National Science Foundation under grants OPP-9912035 and OPP-0240338 to J.G. Bockheim and OPP-9732051 and 0094769 to K.M. Hinkel. Any opinions, findings, conclusions, or recommendations expressed in this material are those of the authors and do not necessarily reflect the views of the NSF. We appreciate the field assistance of N.J. Balster, X.Y.Dai, W.R. Eisner, B. Jones, J.M. Kimble, J. Munroe, F.E. Nelson, J.D. O’Brien, K. Peterson, Y. Shur, and E. Wolfe. We appreciate the constructive comments of C. Burn, R. Sletten, and an anonymous reviewer.

\section{REFERENCES}

AUERBACH, N.A., WALKER, D.A., and BOCKHEIM, J.G. 1996. Land cover of the Kuparuk basin, Alaska (map). Boulder, Colorado: Institute of Arctic and Alpine Research, University of Colorado.1 p.

BOCKHEIM, J.G., and TARNOCAI, C. 1998. Recognition of cryoturbation for classifying permafrost-affected soils. Geoderma 81:281-293.

BOCKHEIM, J.G., TARNOCAI, C., KIMBLE, J.M., and SMITH, C.A.S. 1997. The concept of gelic materials in the new Gelisol order for permafrost-affected soils. Soil Science 162:927-939.
BOCKHEIM, J.G., EVERETT, L.R., HINKEL, K.M., NELSON, F.E., and BROWN, J. 1999. Soil organic carbon storage and distribution in Arctic tundra, Barrow, Alaska. Soil Science Society of America Journal 63:934-940.

BOCKHEIM, J.G., HINKEL, K.M., and NELSON, F.E. 2002. Soils of the Barrow region, Alaska. Polar Geography 25: $163-181$.

BOCKHEIM, J.G., HINKEL, K.M., EISNER, W.R., and DAI, X.Y. 2004. Carbon pools and accumulation rates in an age-series of soils in drained thaw-lake basins, Arctic Alaska. Soil Science Society of America Journal 68:697-704.

BROWN, J. 1965a. Radiocarbon dating, Barrow, Alaska. Arctic $18: 37-48$.

1965b. Concerning genesis of the buried organic matter in tundra soils. Soil Science Society of America Proceedings 29:89-90.

1967a. Tundra soils formed over ice wedges, northern Alaska. Soil Science Society of America Proceedings 31: 686-691.

. 1967b. An estimation of the volume of ground ice, coastal plain, Arctic Alaska. Cold Regions Research and Engineering Laboratory Technical Report. 22 p.

1969. Soil properties developed on the complex tundra relief of northern Alaska. Biuletyn Peryglacjalny 18:153-167.

BROWN, J., EVERETT, K.R., WEBBER, P.J., MACLEAN, S.F., Jr., and MURRAY, D.F. 1980. The coastal tundra at Barrow. In: Brown, J., Miller, P.C., Tieszen, L.L., and Bunnell, F.L., eds. An Arctic ecosystem: The coastal tundra at Barrow, Alaska. Stroudsburg, Pennsylvania: Dowden, Hutchinson \& Ross. $1-33$.

CARTER, L.D. 1988. Loess and deep thermokarst basins in Arctic Alaska. In: Senneset, K., ed. Proceedings of the Fifth International Conference on Permafrost, Vol. 1:706-711. Trondheim: Tapir Publishers.

CHENG, G. 1983. The mechanism of repeated-segregation for the formation of thick layered ground ice. Cold Region Science and Technology 8(1):57-66.

DOUGLAS, L.A., and TEDROW, J.C.F. 1960. Tundra soils of Arctic Alaska. 7th International Congress of Soil Science, Madison, Wisconsin, Vol.5(41):291 -304. Amsterdam: Elsevier.

DREW, J.V. 1957. A pedologic study of Arctic coastal plain soils nearPoint Barrow, Alaska. Ph.D. dissertation, Rutgers University, New Brunswick, New Jersey (Dissertation Abstracts AAC0022512).

DREW, J.V., and TEDROW, J.C.F. 1962. Arctic soil classification and patterned ground. Arctic 5:109-116.

EISNER, W.R., BOCKHEIM, J.G., HINKEL, K.M., BROWN, T.A., NELSON, F.E., PETERSON, K.M., and JONES, B.M. 2005. Paleoenvironmental analyses of an organic deposit from an erosional landscape remnant, Arctic Coastal Plain of Alaska. Palaeogeography, Palaeoclimatolgy, and Palaeoecology 217:187-204.

ESTABROOK, G.F., and OUTCALT, S. 1984. An algorithm for clustering profile data and its application to near-surface ice content data from wet coastal tundra soils near Barrow, Alaska. Mathematical Geology 16:193-205. 
EVERETT, K.R. 1974. Principal soils and geomorphic units of the Barrow sites. International Biological Program, Tundra Biome Data Report 74-7. Hanover, New Hampshire: Cold Regions Research and Engineering. 45 p.

1979. Evolution of the soil landscape in the sand region of the Arctic Coastal Plain as exemplified at Atkasook, Alaska. Arctic 32:207-223.

FOX, C.A., and PROTZ, R. 1981. Definition of fabric distributions to characterize the arrangement of soil particles in the turbic cryosols. Canadian Journal of Soil Science 61:29-34.

HINKEL, K.M., NELSON, F.E., SHUR, Y., BROWN, J., and EVERETT, K.R. 1996. Temporal changes in moisture content of the active layer and near-surface permafrost at Barrow, Alaska: 1962-1994. Arctic and Alpine Research 28(3): 300-310.

HINKEL, K.M., PAETZOLD, R., NELSON, F.E., and BOCKHEIM, J.G. 2001. Patterns of soil temperature and moisture in the active layer and upper permafrost at Barrow, Alaska: 1993 - 1999. Global and Planetary Change 29:293-309.

HINKEL, K.M., EISNER, W.R., BOCKHEIM, J.G., NELSON, F.E., PETERSON, K.M., and DAI, X. 2003. Spatial extent, age and carbon stocks in drained thaw lake basins on the Barrow Peninsula, Alaska. Arctic, Antarctic and Alpine Research 35: 291-300.

HOEFLE, C.M., PING, C.L., and KIMBLE, J.M. 1998. Properties of permafrost soils on the northern Seward Peninsula, northwest Alaska. Soil Science Society of America Journal 62: 1629-1639.

KOKELJ, S.V., and BURN, C.R. 2003. "Drunken forest" and near surface ground ice in Mackenzie Delta, Northwest Territories, Canada. Proceedings of the Eighth International Conference on Permafrost, Vol. 1. Lisse, The Netherlands: A.A. Balkema Publishers. 567-572.

- 2005. Geochemistry of the active layer and near surface permafrost, Mackenzie delta region, Northwest Territories, Canada. Canadian Journal of Earth Sciences 42:37-48.

LACHENBRUCH, A.H. 1962. Mechanics of thermal contraction on cracks and ice wedge polygons in permafrost. Special Paper 70. Washington, D.C.: Geological Society of America. 69 p.

LEWKOWICZ, A.G. 1994. Ice-wedge rejuvenation, Fosheim Peninsula, Ellesmere Island, Canada. Permafrost and Periglacial Processes 5:251-268.

LEWKOWICZ, A.G., and CLARKE, S. 1998. Late-summer solifluction and active layer depths, Fosheim Peninsula, Ellesmere Island, Canada. In: Lewkowicz, A.G., and Allard, M., eds. Proceedings of the Seventh International Conference on Permafrost, 23-27 June 1998, Centre d'études nordiques, Université Laval, Québec. 641-646.

MACKAY, J.R. 1971. Ground ice in the active layer and the top portion of permafrost. In: Brown, R.J.E., ed. Proceedings, Seminar on the Permafrost Active Layer. Memorandum 103. Ottawa: National Research Council of Canada. 26-30.

- 1972. The world of underground ice. Annals of the Association of American Geographers 62:1-22.

1980. The origin of hummocks, western Arctic coast, Canada. Canadian Journal of Earth Sciences 13:889-897.
- 1983. Downward water movement into frozen ground, western Arctic coast, Canada. Canadian Journal of Earth Sciences 20:120-134.

MUNROE, J.S., and BOCKHEIM, J.G. 2001. Soil development in low-Arctic tundra of the northern Brooks Range, Alaska, U.S.A. Arctic, Antarctic and Alpine Research 33:78-87.

MURTON, J.B., and FRENCH, H.M. 1994. Cryostructures in permafrost, Tuktoyaktuk coastlands, western Arctic Canada. Canadian Journal of Earth Sciences 31:737-747.

NATIONAL CLIMATE DATA CENTER. 2002. Climatological data for Barrow, Alaska. http://climate.gi.alaska.edu/Climate/ Location/Arctic/Barrow.html.

NELSON, F.E., OUTCALT, S.I., BROWN, J., SHIKLOMANOV, N.I., and HINKEL, K.M. 1998. Spatial and temporal attributes of the active-layer thickness record, Barrow, Alaska U.S.A. In: Lewkowicz, A.G., and Allard, M., eds. Proceedings of the Seventh International Conference on Permafrost, 23-27 June 1998, Centre d'études nordiques, Université Laval, Québec. $797-802$.

PÉWÉ, T.L. 1975. Quaternary geology of Alaska. United States Geological Survey Professional Paper 835. 145 p.

PING, C.L., BOCKHEIM, J.G., KIMBLE, J.M., MICHAELSEN, G.J., and WALKER, D.A. 1998. Characteristics of cryogenic soils along a latitudinal transect in Arctic Alaska. Journal of Geophysical Research 103(D22):28917-28928.

POLLARD, W., and FRENCH, H.M. 1980. A first approximation of the volume of ground ice, Richards Island, Pleistocene Mackenzie Delta, Northwest Territories, Canada. Canadian Geotechnical Journal 17:509-516.

POPOV, A.I. 1967. Frost features in the earth's crust (cryolithology) (in Russian). Moscow: Moscow State University Press.

SELLMANN, P.V., and BROWN, J. 1973. Stratigraphy and diagenesis of perennially frozen sediment in the Barrow, Alaska region. In: Permafrost: North American Contribution to the Second International Conference. Washington, D.C.: National Academy of Sciences. 171-181.

SELLMANN, P.V., BROWN, J., LEWELLEN, R.I., McKIM, H.L., and MERRY, C.J. 1975. The classification and geomorphic implications of thaw lakes on the arctic coastal plain, Alaska. Research Report 344. Hanover, New Hampshire: U.S. Army Cold Regions Research and Engineering Laboratory.

SHUR, Y.L. 1975. On the transient layer. In: Shvetsov, P.F., and Chistotinov, L.V., eds. Methods of geocryological studies (in Russian). Moscow: USSR Institute of Hydrogeology and Engineering Geology. 82-85.

. 1977. Thermokarst (in Russian). Moscow: Nedra Publishing House.

- 1988a. The upper horizon of permafrost soils. In: Senneset, K., ed. Proceedings of the Fifth International Conference on Permafrost, Vol. 1: 867-871. Trondheim: Tapir Publishers. 1988b. Upper horizon of permafrost and thermokarst (in Russian). Moscow: Nauka. 208 p.

SHUR, Y.L., and PING, C.L. 1994. Permafrost dynamics and soil formation. In: Kimble, J.M., and Ahrens, R.J., eds. Proceedings of the Meeting on Classification, Correlation, and Management of Permafrost-Affected Soils, July 1993. Lincoln, Nebraska: USDA Soil Conservation Service, National Soil Survey Center. $112-117$. 
SHUR, Y., HINKEL, K.M., and NELSON, F.E. 2005. The transient layer: Implications for geocryology and climate-change science. Permafrost and Periglacial Processes 16:5-17.

SMITH, C.A.S., FOX, C.A., and HARGRAVE, A.E. 1991. Development of soil structure in some turbic cryosols in the Canadian low Arctic. Canadian Journal of Soil Science 71: $11-29$.

SOIL CLASSIFICATION WORKING GROUP. 1998. The Canadian system of soil classification. 3rd ed. Ottawa: NRC Research Press.

SOIL SURVEY STAFF. 1999. Soil taxonomy: A basic system of soil classification for making and interpreting soil surveys. Agricultural Handbook Number 436. Washington, D.C.: United States Department of Agriculture, Natural Resources Conservation Service, Superintendent of Documents, United States Government Printing Office.

TARNOCAI, C. 1972. Some characteristics of cryic organic soils in northern Manitoba. Canadian Journal of Soil Science 52: $485-496$.

- 1983. Soils and vegetation. In: French, H.M., and Heginbottom, J.A., eds. Northern Yukon Territory and Mackenzie Delta, Canada: Guidebook to permafrost and related features. Guidebook 3. Fairbanks, Alaska: International Conference on Permafrost. 21-34.

- 1994. Genesis of permafrost-affected soils. In: Kimble, J.M., and Ahrens, R.J., eds. Proceedings of the Meeting on Classification, Correlation, and Management of PermafrostAffected Soils, July 1993. Lincoln, Nebraska: USDA Soil Conservation Service, National Soil Survey Center. 143-154.

TARNOCAI, C., and ZOLTAI, S.C. 1978. Earth hummocks of the Canadian Arctic and Subarctic. Arctic and Alpine Research 10:581-594.

TEDROW, J.C.F. 1962. Morphological evidence of frost action in soils. Biuletyn Peryglacjalny 11:343-352.

TWEEDIE, C.E., HUEMMRICH, R., HOLLISTER, R.D., GAMON, J.A., KINOSHITA, G., WEBBER, P.J., NOYLE, B.,
KARWAN, D., OBERBAUER, S., KUCHY, A., OECHEL, W.C., HOUSTON, S., ANDERSON, E., KWON, H., ZULUETA, R.C., VERFAILLIE, J., and GAGE, S. 2004. Land cover classification and modeling of ecosystem carbon flux in the Barrow Environmental Observatory using IKONOS satellite imagery. www.cevl.msu.edu/ael/posters/ikonos-landcover.html. Accessed 26 September 2004.

VAN EVERDINGEN, R.O., ed. 1998. Multi-language glossary on permafrost and related ground ice terms. Calgary, Alberta: International Permafrost Association.

VAN VLIET-LANOË, B. 1988. The significance of cryoturbation phenomena in environmental reconstruction. Journal of Quaternary Science 3:85-96.

- 1991. Differential frost, load casting and convection: Converging mechanisms; a discussion of the origin of cryoturbations. Permafrost and Periglacial Processes 2: $123-139$.

WALKER, D.A., and EVERETT, K.R. 1991. Loess ecosystems of northern Alaska: Regional gradient and toposequence at Prudhoe Bay. Ecological Monographs 61:437-464.

WALKER, D.A., BOCKHEIM, J.G., CHAPIN, F.S., III, EUGSTER, W., NELSON, F.E., and PING, C.L. 2000. Calcium-rich tundra, wildlife, and the "Mammoth Steppe." Quaternary Science Reviews 20:149-163.

WASHBURN, A.L. 1980. Geocryology. New York: J. Wiley. WILLIAMS, P.J. 1982. The surface of the earth. New York: Longman.

YANOVSKY, V.K. 1933. Expedition to Pechora River to determine the position of the southern permafrost boundary. In: Reports of the Committee for Permafrost Investigations. MoscowLeningrad: Akademiia Nauk SSSR. Vol. 5(2):65-149.

ZOLTAI, S.C., TARNOCAI, C., and PETTAPIECE, W.W. 1978. Age of cryoturbated materials in earth hummocks from the Canadian Arctic. Proceedings of the Third International Conference on Permafrost, Edmonton, Alberta, Canada. Ottawa: National Research Council of Canada. 326-331. 